\title{
CD96 Gene
}

National Cancer Institute

\section{Source}

National Cancer Institute. CD96 Gene. NCI Thesaurus. Code C157300.

This gene may play a role in T-cell and natural killer (NK) cell adhesion. 